\title{
Optimal parameters of physical and mechanical properties of sawdust concrete
}

\author{
Nikolay Plotnikov ${ }^{1, *}$ and Olga Burova $^{2}$ \\ ${ }^{1}$ Bratsk State University, 665709, Makarenko Street 40, Irkutsk region, city of Bratsk, Russia \\ ${ }^{2}$ Moscow State University of Civil Engineering, 26, Yaroslavskoye shosse, Moscow, 129337, Russia
}

\begin{abstract}
The purpose of the conducted experimental studies is to examine the effect of various influences on the object of study. These effects are called factors. Some of them vary while examining of the object and then they are called variable factors. Each factor takes one or more values in the experiment and then they are called factor levels. The set of values of this factor is called range of factor values - the smallest interval, where are all the values accepted by this factor in the experiment. According to GOST 19222-84, the dependence of the physical-mechanical characteristics of sawdust slag concrete (grade M10) on the specific gravity (share) of wet sawdust of coniferous species and ash-slag mixture in the composition was studied. Regression analysis was used to build a mathematical model of the process with quantitative factors, to verify its adequacy, and to assess the impact of each variable factor on the process. To obtain regression dependencies, a composite second-order B-plan was implemented.
\end{abstract}

\section{Introduction}

The purpose of the conducted experimental studies is to examine the effect of various influences on the object of study. These effects are called factors. Some of them vary while examining of the object and then they are called variable factors. Each factor takes one or more values in the experiment and then they are called factor levels. The set of values of this factor is called range of factor values - the smallest interval, where are all the values accepted by this factor in the experiment [1-9].

\section{Materials and methods}

A two-factor experiment was carried out in the laboratory of the Department of Reproduction and Processing of Forest Resources, Federal State Budgetary Educational Institution of Higher Education "Bratsk State University" in order to justify the specific share of wet sawdust in the composition of sawdust concrete, to determine the necessary number of observations and repetitions of the experiment. As a variable factor, the

\footnotetext{
* Corresponding author: n-plotnikov@mail.ru
} 
proportion of wet sawdust of coniferous species in the composition is assumed. The proportion varies from $17 \%$ to $37 \%$ in increments of 5\% [10-18].

The qualitative indicators of the final product (heat-insulating sawdust concrete of grade M10) were taken as output values:

Y1 - average density, $\rho$ avg, $\mathrm{kg} / \mathrm{m} 3$;

Y2 - humidity, W, \%;

$\mathrm{Y} 3$ - compressive strength, $\sigma \mathrm{cf}, \mathrm{MPa}$;

Y4 - sorption moisture, As, \%.

Variable experiment factors:

$\mathrm{X} 1$ - percentage of wet sawdust of coniferous species in the composition, dsd, \%;

$\mathrm{X} 2$ - percentage of ash-slag mixture from the volume of air-slaked lime in the composition, das, $\%$.

\section{Results}

Based on these requirements, the range of variation of variable factors is assumed equal to $5 \%$. Tab. 1 shows the variable factors in natural and code designation, their levels and range of variation, when conducting a two-factor experiment.

Table 1. Main factors and their levels of variation.

\begin{tabular}{|c|c|c|c|c|c|}
\hline Name of the factor & $\begin{array}{c}\text { Design } \\
\text { a-tion }\end{array}$ & $\begin{array}{c}\text { Lower } \\
\text { level }\end{array}$ & $\begin{array}{c}\text { Main } \\
\text { level }\end{array}$ & $\begin{array}{c}\text { Upper } \\
\text { level }\end{array}$ & $\begin{array}{c}\text { Range of } \\
\text { variation }\end{array}$ \\
\hline $\begin{array}{l}\text { The proportion of wet } \\
\text { sawdust of coniferous } \\
\text { species in the } \\
\text { composition, \% }\end{array}$ & $\mathrm{X}_{1}$ & 17 & 27 & 37 & 10 \\
\hline $\begin{array}{l}\text { The proportion of ash-slag } \\
\text { mixture from the volume } \\
\text { of lime, \% }\end{array}$ & $\mathrm{X}_{2}$ & 0 & 12,5 & 25 & 12,5 \\
\hline
\end{tabular}

The constant factors of the experiment have the following meanings:

- air temperature $23 \pm 1{ }^{\circ} \mathrm{C}$;

- air humidity $45 \pm 5 \%$;

- species composition of sawdust - coniferous;

- moisture content of sawdust $-6.0 \pm 0.1 \%$;

- fractional composition of sawdust $-0.5 \ldots 5 \mathrm{~mm}$;

- the size of the obtained samples - 100x100x100 mm;

- air-slaked lime consumption - $25.0 \mathrm{~kg}$ per $1 \mathrm{~m} 3$ of the mixture;

- sand consumption - $265.8 \mathrm{~kg}$ per $1 \mathrm{~m} 3$ of the mixture;

- water consumption - 300.01 per $1 \mathrm{~m} 3$ of the mixture;

- water glass consumption $-8.0 \mathrm{~kg}$ per $1 \mathrm{~m} 3$ of the mixture.

According to GOST 19222-84, the dependence of the physical-mechanical characteristics of sawdust slag concrete (grade M10) on the specific gravity (share) of wet sawdust of coniferous species and ash-slag mixture in the composition was studied.

Regression analysis was used to build a mathematical model of the process with quantitative factors, to verify its adequacy, and to assess the impact of each variable factor on the process.

To obtain regression dependencies, a composite second-order B-plan was implemented.

The planning matrix of the experiment is presented in Tab. 2. 
At the next stage, a multi-factorial experiment was conducted in order to obtain an adequate mathematical description of the technological production of sawdust slag concrete of the proposed composition.

Table 2. Planning matrix for two controllable factors.

\begin{tabular}{|c|c|c|c|c|c|c|c|c|}
\hline $\begin{array}{c}\text { Experiment } \\
\text { number }\end{array}$ & $\mathrm{x}_{1}$ & $\begin{array}{c}\mathrm{X}_{1}, \\
\mathrm{~d}_{\text {dd }}, \\
\%\end{array}$ & $\mathrm{x}_{2}$ & $\begin{array}{c}\mathrm{X}_{2,}, \\
\mathrm{~d}_{\mathrm{as}}, \\
\%\end{array}$ & $\begin{array}{c}\mathrm{Y}_{1}, \\
\rho, \\
\mathrm{kg} / \mathrm{m}^{3}\end{array}$ & $\begin{array}{c}\mathrm{Y}_{2}, \\
W, \\
\%\end{array}$ & $\begin{array}{c}\mathrm{Y}_{3}, \\
\sigma_{c f,} \\
\mathrm{MPa}\end{array}$ & $\begin{array}{c}\mathrm{Y}_{4}, \\
A_{\mathrm{s}}, \\
\%\end{array}$ \\
\hline 1 & 2 & 3 & 4 & 5 & 6 & 7 & 8 & 9 \\
\hline 1 & -1 & 17 & -1 & 0 & $\mathrm{Y}_{11}$ & $\mathrm{Y}_{21}$ & $\mathrm{Y}_{31}$ & $\mathrm{Y}_{41}$ \\
\hline 2 & +1 & 37 & -1 & 0 & $\mathrm{Y}_{12}$ & $\mathrm{Y}_{22}$ & $\mathrm{Y}_{32}$ & $\mathrm{Y}_{42}$ \\
\hline 3 & -1 & 17 & +1 & 25 & $\mathrm{Y}_{13}$ & $\mathrm{Y}_{23}$ & $\mathrm{Y}_{33}$ & $\mathrm{Y}_{43}$ \\
\hline 4 & +1 & 37 & +1 & 25 & $\mathrm{Y}_{14}$ & $\mathrm{Y}_{24}$ & $\mathrm{Y}_{34}$ & $\mathrm{Y}_{44}$ \\
\hline 5 & -1 & 17 & 0 & 12,5 & $\mathrm{Y}_{15}$ & $\mathrm{Y}_{25}$ & $\mathrm{Y}_{35}$ & $\mathrm{Y}_{45}$ \\
\hline 6 & +1 & 37 & 0 & 12,5 & $\mathrm{Y}_{16}$ & $\mathrm{Y}_{26}$ & $\mathrm{Y}_{36}$ & $\mathrm{Y}_{46}$ \\
\hline 7 & 0 & 27 & -1 & 0 & $\mathrm{Y}_{17}$ & $\mathrm{Y}_{27}$ & $\mathrm{Y}_{37}$ & $\mathrm{Y}_{47}$ \\
\hline 8 & 0 & 27 & +1 & 25 & $\mathrm{Y}_{18}$ & $\mathrm{Y}_{28}$ & $\mathrm{Y}_{38}$ & $\mathrm{Y}_{48}$ \\
\hline
\end{tabular}

Tab. 3 shows the obtained values of the output parameters combined with the planning matrix of the experiment according to a composite second-order B-plan in normalized and natural designation of variable factors.

Table 3. Results of a two-factor experiment.

\begin{tabular}{|c|c|c|c|c|c|c|c|c|}
\hline $\begin{array}{c}\text { Experiment } \\
\text { number }\end{array}$ & $\mathrm{x}_{1}$ & $\begin{array}{c}\mathrm{X}_{1}, \\
\mathrm{~d}_{\mathrm{sd}}, \\
\%\end{array}$ & $\mathrm{x}_{2}$ & $\begin{array}{c}\mathrm{X}_{2}, \\
\mathrm{~d}_{\mathrm{s},}, \\
\%\end{array}$ & $\begin{array}{c}\mathrm{Y}_{1}, \\
\rho, \\
\mathrm{kg} / \mathrm{m}^{3}\end{array}$ & $\begin{array}{c}\mathrm{Y}_{2}, \\
W, \\
\%\end{array}$ & $\begin{array}{c}\mathrm{Y}_{3}, \\
\sigma_{c f}, \\
\mathrm{MPa}\end{array}$ & $\begin{array}{c}\mathrm{Y}_{4}, \\
A_{s}, \\
\mathbf{\%}\end{array}$ \\
\hline 1 & -1 & 17 & -1 & 0 & 457,0 & 24,6 & 2,5 & 6,3 \\
\hline 2 & +1 & 37 & -1 & 0 & 449,6 & 25,1 & 1,2 & 6,9 \\
\hline 3 & -1 & 17 & +1 & 25 & 582,8 & 17,7 & 2,3 & 1,4 \\
\hline 4 & +1 & 37 & +1 & 25 & 566,5 & 18,2 & 1,3 & 2,1 \\
\hline 5 & -1 & 17 & 0 & 12,5 & 519,9 & 21,1 & 2,4 & 3,8 \\
\hline 6 & +1 & 37 & 0 & 12,5 & 503,7 & 21,6 & 1,4 & 4,5 \\
\hline 7 & 0 & 27 & -1 & 0 & 453,4 & 24,8 & 1,8 & 6,6 \\
\hline 8 & 0 & 27 & +1 & 25 & 574,7 & 17,9 & 1,9 & 1,7 \\
\hline
\end{tabular}

A mathematical description of the dependence of standardized by GOST 19222-84 physical-mechanical characteristics of sawdust slag concrete (density, humidity, strength, sorption moisture) on the variable technological parameters is presented in the form of a standardized regression equation:

- density, $(\mathrm{Y} 1, \rho), \mathrm{kg} / \mathrm{m} 3$ :

$\mathrm{Y} 1=511,785-6,64 \mathrm{x} 1+60,6667 \times 2-0,075 \times 21+2,175 \times 22-2,225 \times 1 \times 2$

- humidity, (Y2, W), \%:

$\mathrm{Y} 2=21,3+0,25 \times 1-3,45 \times 2-0,05 \times 21+0,05 \times 22$

- strength, (Y3, ocf ), MPa:

$\mathrm{Y} 3=1,9-0,5833 \times 1-0,0167 \times 2-0,05 \times 21-0,056 \times 22+0,056 \times 1 \times 2$

- sorption moisture, (Y4, As), \%:

$\mathrm{Y} 4=4,125+0,3333 \times 1-2,4333 \times 2+0,025 \times 21+0,025 \times 22+0,025 \times 1 \times 2$

After evaluating the significance of the regression coefficients and conversion the factors to the natural values, the equations of the response functions take the following form: 
- density, $\mathrm{kg} / \mathrm{m} 3$ : *das

$\boldsymbol{\rho}=464,7841-0,402 * \mathrm{dsd}+4,9859 * \mathrm{das}-0,0007 * \mathrm{dsd} 2+0,0139 * \mathrm{das} 2-0,0178 * \mathrm{dsd}$

- humidity, \%:

$\mathrm{W}=24,634-0,002 * \mathrm{dsd}-0,284 *$ das

- compressive strength, $\mathrm{MPa}$ :

$\boldsymbol{\sigma c f},=3,2122-0,0363 *$ dsd $-0,0003 *$ das $2+0,0004 *$ dsd $*$ das

- sorption moisture, $\%$ :

As $=5,998+0,0173 *$ dsd $-0,2041 *$ das

Based on the obtained regression equations, dependency graphs were created. A graph of the density of sawdust slag concrete on the proportion of sawdust and ash-slag mixture in the composition is shown in Fig. 1.

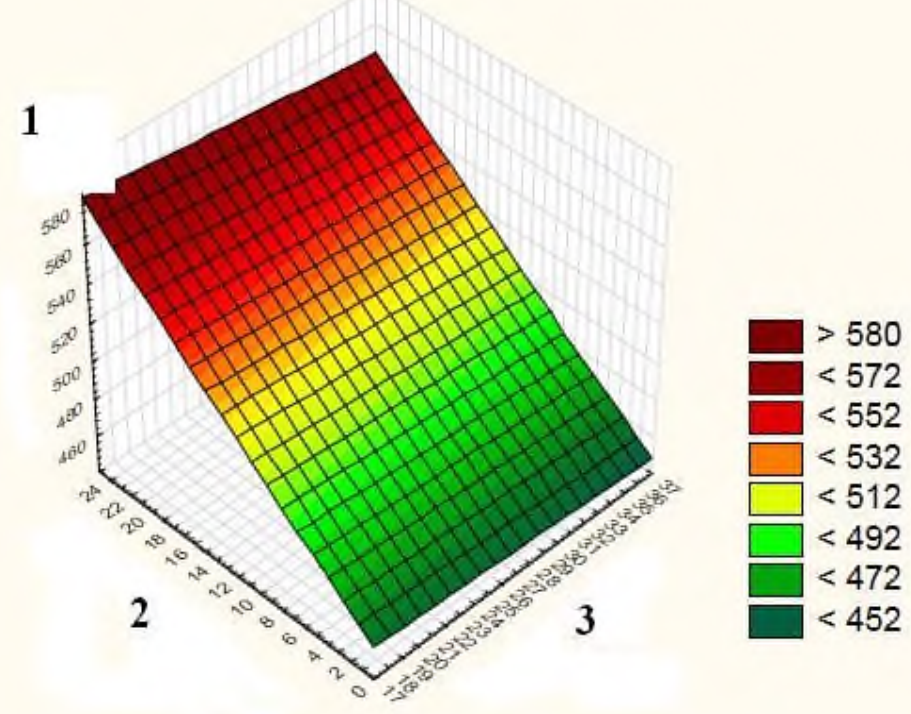

1 - Density, $\rho, \mathrm{kg} / \mathrm{m}^{3}$

2 - The proportion of ash-slag mixture from the volume of lime in the composition, $\%$

3 - The proportion of sawdust in the composition, $\%$

Fig. 1. Graph of the density of sawdust slag concrete on the proportion of sawdust and ash-slag mixture in the composition.

According to GOST 19222-84, the density of heat-insulating sawdust concrete of grade M10 should be in the range from 450 to $500 \mathrm{~kg} / \mathrm{m} 3$. Based on the data obtained, it is possible to judge the compliance of the quality of the tested samples with the requirements of GOST.

The minimum density of sawdust slag concrete of the proposed composition (449.6 $\mathrm{kg} / \mathrm{m} 3$ ) is observed when the proportion of wet sawdust of coniferous species in the composition is $37 \%$, and ash-slag mixture is absent. The maximum density of sawdust slag concrete $(582.8 \mathrm{~kg} / \mathrm{m} 3)$ is achieved when the proportion of wet sawdust of coniferous species in the composition is $17 \%$, and the proportion of ash-slag mixture is $25 \%$.

The dependence of the moisture content of sawdust slag concrete on the proportion of sawdust and ash-slag mixture in the composition is shown in Fig. 2.

According to GOST 19222-84, the humidity of heat-insulating sawdust concrete of grade M10 should not exceed 25\%. Based on the data obtained, it is possible to judge the compliance of the quality of the tested samples with the requirements of GOST. 


\section{EMMFT-2020}

The minimum moisture content of sawdust slag concrete of the proposed composition $(17.7 \%)$ is observed when the proportion of wet sawdust of coniferous species in the composition is $17 \%$, and the proportion of ash-slag mixture is $25 \%$. The maximum moisture content of sawdust slag concrete $(25.1 \%)$ is achieved when the proportion of wet sawdust of coniferous species in the composition is $37 \%$, and ash-slag mixture is absent.

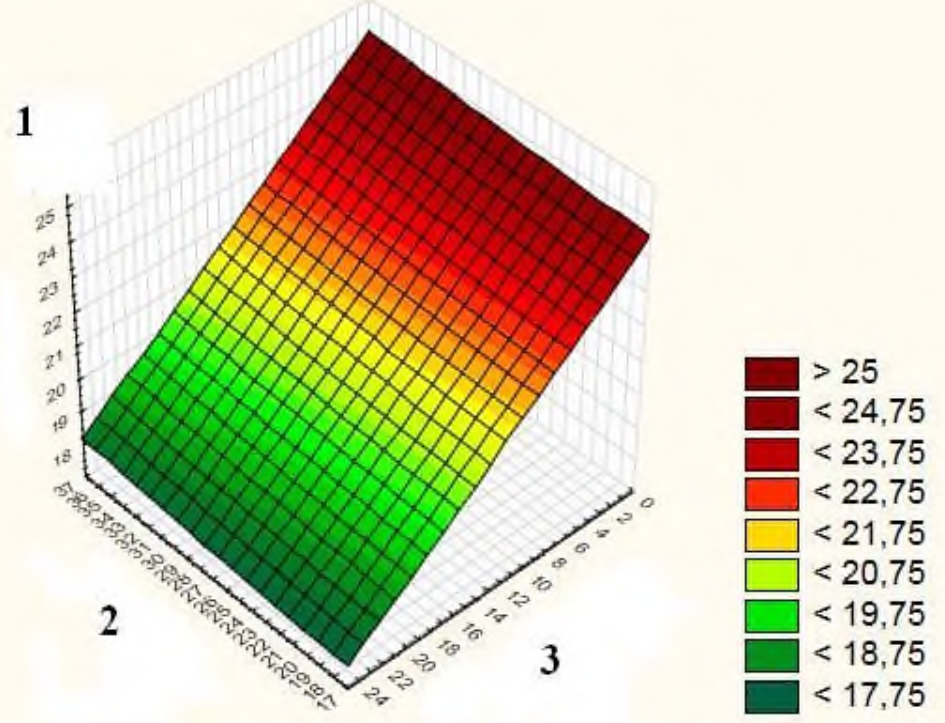

1 - Humidity, \%

2 - The proportion of sawdust in the composition, $\%$

3 - The proportion of ash-slag mixture from the volume of lime in the composition, \%

Fig. 2. Graph of the moisture content of sawdust slag concrete on the proportion of sawdust and ashslag mixture in the composition.

The dependence of sawdust slag concrete strength on the proportion of sawdust and ashslag mixture in the composition is shown in Fig. 3.

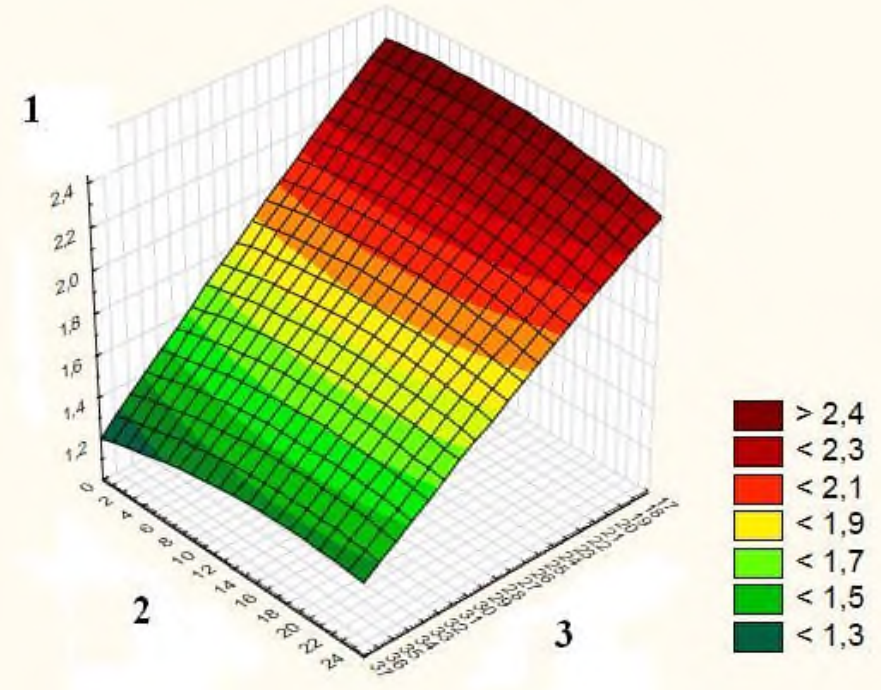


2 - The proportion of ash-slag mixture from the volume of lime in the composition, $\%$ 3 - The proportion of sawdust in the composition, \%

Fig. 3. Graph of the strength of sawdust slag concrete on the proportion of sawdust and ash-slag mixture in the composition.

According to GOST 19222-84, the strength of heat-insulating sawdust concrete of grade M10 should be in the range from 1.5 to $2.5 \mathrm{MPa}$. Based on the data obtained, it is possible to judge the compliance of the quality of the tested samples with the requirements of GOST.

The minimum strength of sawdust slag concrete of the proposed composition (1.2 MPa) is observed when proportion of wet sawdust of coniferous species in the composition is $37 \%$, and ash-slag mixture is absent. The maximum strength of sawdust slag concrete $(2.5$ $\mathrm{MPa}$ ) is achieved when the proportion of wet sawdust of coniferous species in the composition is $17 \%$, and ash and slag mixture is absent.

A graph of the dependence of the sorption moisture of the samples on the proportion of sawdust and ash-slag mixture in the composition is shown in Fig. 4.

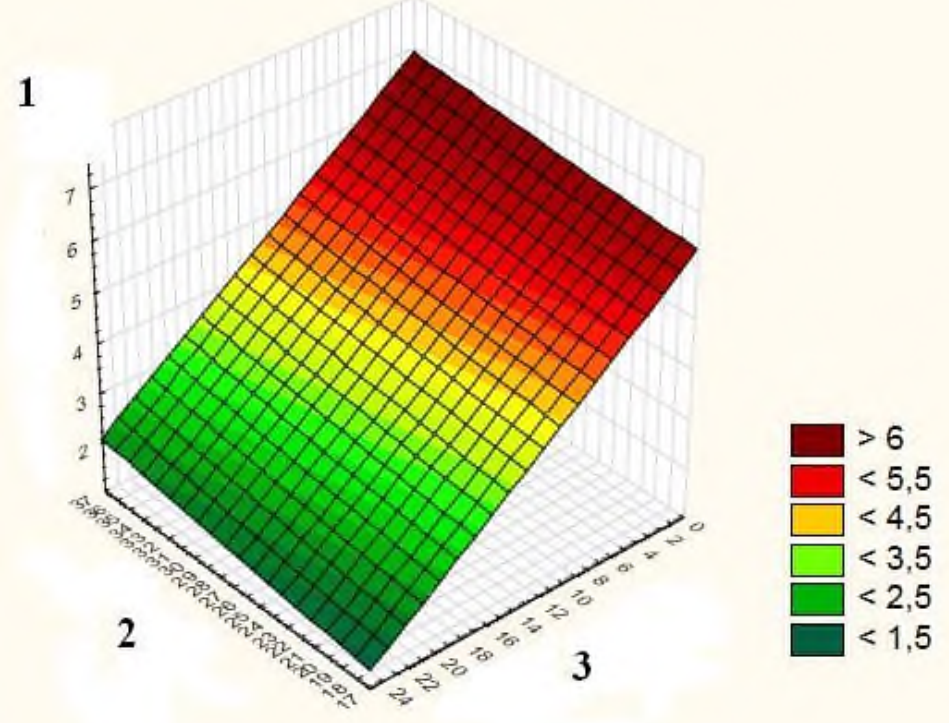

1- Sorption moisture, \%

2 - The proportion of sawdust in the composition, $\%$

3 - The proportion of ash-slag mixture from the volume of lime in the composition, $\%$

Fig. 4. Graph of the sorption moisture of sawdust slag concrete on the proportion of sawdust and ashslag mixture in the composition.

According to GOST 19222-84, the sorption moisture of heat-insulating sawdust concrete of grade M10 should be in the range from 4 to $8 \%$. Based on the data obtained, it is possible to judge the compliance of the quality of the tested samples with the requirements of GOST.

The minimum sorption moisture content of sawdust slag concrete of the proposed composition (1.4\%) is observed when the proportion of wet sawdust of coniferous species in the composition is $17 \%$, and the proportion of ash-slag mixture is $25 \%$. The maximum sorption moisture content of sawdust slag concrete $(6.9 \%)$ is achieved when the proportion of wet sawdust of coniferous species in the composition is $37 \%$, and ash-slag mixture is absent. 


\section{Conclusions}

1. The minimum density of sawdust slag concrete of the proposed composition (449.6 $\mathrm{kg} / \mathrm{m} 3$ ) is observed when the proportion of wet sawdust of coniferous species in the composition is $37 \%$, and ash-slag mixture is absent. The maximum density of sawdust slag concrete $(582.8 \mathrm{~kg} / \mathrm{m} 3)$ is achieved when the proportion of wet sawdust of coniferous species in the composition is $17 \%$, and the proportion of ash-slag mixture is $25 \%$.

2. The minimum moisture content of sawdust slag concrete of the proposed composition $(17.7 \%)$ is observed when the proportion of wet sawdust of coniferous species in the composition is $17 \%$, and the proportion of ash-slag mixture is $25 \%$. The maximum moisture content of sawdust slag concrete $(25.1 \%)$ is achieved when the proportion of wet sawdust of coniferous species in the composition is $37 \%$, and ash-slag mixture is absent.

3. The minimum strength of sawdust slag concrete of the proposed composition $(1.2$ $\mathrm{MPa}$ ) is observed when proportion of wet sawdust of coniferous species in the composition is $37 \%$, and ash-slag mixture is absent. The maximum strength of sawdust slag concrete $(2.5 \mathrm{MPa})$ is achieved when the proportion of wet sawdust of coniferous species in the composition is $17 \%$, and ash and slag mixture is absent.

4. The minimum sorption moisture content of sawdust slag concrete of the proposed composition (1.4\%) is observed when the proportion of wet sawdust of coniferous species in the composition is $17 \%$, and the proportion of ash-slag mixture is $25 \%$. The maximum sorption moisture content of sawdust slag concrete $(6.9 \%)$ is achieved when the proportion of wet sawdust of coniferous species in the composition is $37 \%$, and ash-slag mixture is absent.

\section{References}

1. R.R. Khasanshin, R.R. Safin, P.A. Kainov, A.V. Safina, I.A. Valeev, Effect of process pressure on the yield of products and the duration of the process of thermochemical processing of wood waste. 19th International scientific geoconferense SGEM 2019 Conference proceedings, Sofia, 145-152 (2019)

2. S.P.J.M. Carrot,. M.M.L.R. Carrot., Lignin - from natural adsorbent to activated carbon: a review, Bioresource Technology 98, 2301-2312 (2007)

3. R.R. Safin, F.V. Nazipova, R.R. Khasanshin, A.E. Voronin, Pre-treatment of vegetable waste in the production of composite materials, Key Engineering Materials 743, 53-57 (2017)

4. R.R. Safin, F.V. Nazipova, R.R. Ziatdinov, A.R. Shaikhutdinova, E.A. Beliakova, P.A. Kainov, S. Barcík, The effect of ultrasonic extraction of soluble sugars from the wood filler on the strength properties of the composite based on mineral binder, Key Engineering Materials 688, 138-144 (2016)

5. R.R. Safin, A.F. Zamilova, M.F. Galikhanov, R.R. Ziatdinov, A.F. Garaeva, Intensive technology of creation of the high-strength and moisture resistant plywood materials. International Multidisciplinary Scientific GeoConference Surveying Geology and Mining Ecology Management, SGEM 17, Nano, Bio and Green - Technologies for a Sustainable Future, 231-238 (2017)

6. R.R. Safin, G.F. Ilalova, R.R. Khasanshin, Study of pyrolysis of annual crop refuse under reduced pressure, Solid State Phenomena 299, 974-979 (2020)

7. R.R. Safin, N.R. Galyavetdinov, Sh.R. Mukhametzyanov, A.R. Shaikhutdinova, R.R. Khasanshin, Technology for producing high-qualoty natural biodegradable plastic fpr 
$3 d$ printer. 19th International scientific geoconferense SGEM 2019 Conference proceedings, Sofia, 503-510 (2019)

8. I.H. Nanazashvili, Wood waste - the second life. Arbolite wall blocks, Construction materials, equipment, technologies of the XXI century 7, 24-25 (2011)

9. S.I. Sushkov, The possibility of using wood waste in construction, Actual directions of scientific research of the XXI century: theory and practice, 2, 170-176 (2014)

10. M.V. Filichkina, Conducting multi-factor planning of an experiment for analyzing the structure of an opilkobetonnoy mixture, Actual directions of scientific research of the XXI century: theory and practice, 2, 71-78 (2014)

11. M.V. Tsyganova, Possible ways of processing of wastes of woodworking enterprises, Current directions scientific research of the XXI century: theory and practice, 2, 122127 (2014)

12. E.A. Berezina, V.A. Repin, The possibility of using arbolite in frame multi-storey construction / In the collection: Topical issues of modern science: a collection of articles based on the materials of the XVII International Scientific and practical conference, 56-59 (2018)

13. O.V. Efremova, Development of the composition and technology of wood-slag composite material: dis. candidate of technical sciences (Cherepovets, 2013)

14. G.P. Plotnikova, N.P. Plotnikov, E.A. Kuzminih, The use of hydrolytic lignin in the production of wood-polymer composites, System. Methods. Technology 4, 133-138 (2013)

15. N.P. Plotnikov, G.P. Plotnikova, S.H. Simonyan, Modeling of technological process of wood composite material production of woodworking and wood chemical complex wastes, International Journal of Applied Engineering Research 10 (6), 15131-15139 (2015)

16. N.P. Plotnikov, G.P. Plotnikova, Application of lignin in production wood-polymer composites, E3S Web of Conferences. Topical Problems of Green Architecture, Civil and Environmental Engineering, TPACEE 2019. P. 14011 (2020)

17. N.P. Plotnikov, G.P. Plotnikova, Structure of naphtol modified urea-formaldehyde resins by using the method of nuclear magnetic resonance, Research Journal of Pharmaceutical, Biological and Chemical Sciences. 5(6), 1466-1472 (2014)

18. G.P. Plotnikova, N.P. Plotnikov, Optimization of the production process of chipboard on a modified binder with the use of substandard raw materials, Bulletin of KrasSAU 9, 249-256 (2013) 